UDK 811.161.1'366.52

Izvorni znanstveni članak

Prihvaćeno za tisak: 10. rujna 2018.

https://doi.org/10.22210/suvlin.2018.086.08

Olga Steriopolo

Leibniz-Zentrum Allgemeine Sprachwissenschaft (ZAS)

steriopolo(at)leibniz-zas.de

\title{
Russian evaluative nominalizing suffixes and change in gender
}

\begin{abstract}
This is a study of Russian evaluative nominalizing suffixes with the ability to produce a change in syntactic category and category features of the base, such as animacy, declension class, and gender. The majority of these suffixes consistently form animate evaluative derivations of declension class II (- $a$-declension). However, when it comes to grammatical gender, there appears to be no consistency in gender of evaluative derivations. Thus, non-kinship bases are subject to change in gender and consistently produce evaluative derivations of common gender (masculine or feminine). Kinship bases, in comparison, do not change their gender at all. I propose an analysis of this phenomenon within the framework of Distributed Morphology. This work will be of interest to theoretical linguists, language typologists, Russian linguists and educators, as well as anybody interested in grammatical gender.
\end{abstract}

\section{Introduction}

This is a study of Russian nominalizing evaluative suffixes, such as -an, -jash, -jon, -ul, -un, -ur, -us, -ush, -ag, -jak, -al, -jar, -akh, -il, -in, -ob, -ot, -okh, -jug, $-u k$, and $-u k h$. Suffixes of this kind can attach to various syntactic categories, e.g., adjectives, verbs, nouns, and always form nouns of the second declension (-a-declension or class II). Interestingly, these suffixes can change syntactic category, animacy, declension class, and the gender of the base. This, however, is not the case for kinship nouns, as their gender does not change.

For example, in (1), the evaluative affectionate suffix $-u l$ attaches to an inanimate feminine noun krasota 'beauty'. The resulting evaluative noun krasotulja 'pretty person (affect)' is an animate noun of common gender, as it can trigger either masculine or feminine gender agreements. Thus, in this example, we observe a change in animacy and gender of the base.
(1) a. kras-ot-a
pretty/red-NOM-NOM.SG
(INANIM; FEM)
'beauty'
b. kras-ot-ul-ja$$
\text { pretty/red-NOM-EVAL-NOM.SG }
$$$$
\text { (ANIM; COMMON GENDER) }
$$$$
\text { 'pretty person (affect)' }
$$ 
However, in (2), when the suffix -ul attaches to the masculine kinship noun syn 'son', there is no change in the gender of the base and the resulting noun is also masculine. We do observe, however, a change in declension class: syn 'son' belongs to the declension class I (-ø-ending in nom.sg), while synulja belongs to the declension class II ( $-a$-ending in nom.sg).
(2) a. syn
b. syn-ul-ja
son.NOM.SG (ANIM; MASC; CLASS I)
SOn-EVAL-NOM.SG (ANIM; MASC; CLASS II) 'son' 'son (affect)'

The data above prompt the following questions: (i) How can we account for a change in syntactic category and category features of the base (animacy, declension class and gender) when the evaluative suffixes attach? And (ii) why do kinship nouns behave differently from non-kinship nouns in terms of the absence of gender change?

This research is conducted within the framework of Distributed Morphology (DM) (Halle and Marantz 1993; Halle 1997; Marantz 1997, among many others), which distinguishes between word formation from $\sqrt{ }$ roots and from syntactic categories. The central claim of DM is that there is no division between syntax and morphology. DM differs from descriptivist frameworks, which view categorization in terms of inflection vs. derivation as something that has been proved problematic with respect to the behavior of evaluative derivations (Brown and Hippisley 2012; Dressler and Barbaresi 1994; Manova 2004; Scalise 1984, 1988; Stump 1991, 2001; Vinogradov 1972; among others). It has been shown in the literature that the behavior of evaluative derivations is not wholly inflectional or derivational. In contrast, DM regards inflection and derivation not as primitives, but as derived notions, thus allowing this framework to better account for the behavior of nominalizing evaluative suffixes in Russian.

This work is organized as follows. In §2, I present Russian data with nominalizing evaluative suffixes. In $\S 3$, I propose an analysis of the data. In $\S 4$, I present the conclusions.

\section{Data ${ }^{1}$ and Questions}

The Russian nominalizing evaluative suffixes under investigation are listed in table 1.

\begin{tabular}{|l|l|}
\hline Affectionate suffixes & $-a n,-j a s h,-j o n,-u l,-u n,-u r,-u s,-u s h$ \\
\hline Vulgar suffixes & $-a g,-j a k,-a l,-j a r,-a k h,-i l,-i n,-o b,-o t,-o k h,-j u g,-u k,-u k h$ \\
\hline
\end{tabular}

Table 1: Russian evaluative suffixes (from Steriopolo 2008: 62)

1 The data, unless otherwise specified, are taken from Steriopolo (2008), where they are cited from Stankiewicz (1968) and a number of academy grammars. 
These suffixes have the following common properties. First, they all carry evaluative meanings expressing the speaker's attitude (affectionate or vulgar) and are productively used in colloquial Russian, as shown in (3) and (4).

(3) a.pap-a

dad-NOM.SG (MASC; CLASS II) 'dad'

(4) a. vor

$$
\begin{aligned}
& \text { thief.NOM.SG (MASC; CLASS I) } \\
& \text { 'thief' }
\end{aligned}
$$

b. pap-ul-ja dad-EVAL-NOM.SG (MASC; CLASS II) 'dad (affect)'

b. vor-jug $-a$ thief-EVAL-NOM.SG (MASC/FEM; CLASS II) 'thief (vulg)'

Second, they can attach to various syntactic categories and always form nouns, as in (5) and (6).

(5) ADJECTIVE $\Rightarrow$ NOUN
a. grjaz $-n-y j$
b. grjaz-n-ukh-a
dirty-ADJ-MASC.NOM.SG
dirty-ADJ-EVAL-NOM.SG
(MASC/FEM; CLASS II)
'dirty'
'dirty person (vulg)'

(6) VERB $\Rightarrow$ NOUN
a. raster-ja-t'
b. raster-jash $-a$
lose-TH-INF
'to lose'
lose-EVAL-NOM.SG (MASC/FEM; CLASS II) 'person wholoses things (affect)'

Third, they always form nouns of the-a-declension (or class II), as in (7) and (8).

(7) CLASS I $\Rightarrow$ CLASS II
a. syn
SOn.NOM.SG (MASC; CLASS I)
b. syn-ul-ja
son-EVAL-NOM.SG (MASC; CLASS II)
'son (affect)'

(8) CLASS II $\Rightarrow$ cLASS II
a. $m a m-a$
b. $m a m-u l-j a$
mother-NOM.SG (FEM; CLASS II)
'mother'
mother-EVAL-NOM.SG (FEM; CLASS II)
'mother (affect)'

\subsection{Animacy}

The majority of these suffixes consistently form animate nouns. They typically refer to humans - as in (9b) and (10b) - but can also be used in reference to anthropomorphic animals, such as pets. Two vulgar suffixes, $-o b$ and $-o t$, are the exception to this rule: they can only attach to inanimate bases and form inanimate nouns, as in (11b), (12b). 
(9) INANIM $\Rightarrow$ ANIM
a. slast'
sweet.NOM.SG (FEM; CLASS III)
'sweet'

(10) a. kras-ot-a

pretty/red-NOM-NOM.SG

(FEM; CLASS II)

'beauty'

(11) INANIM = INANIM

a. styd shame.NOM.SG (MASC; CLASS I) 'shame'

(12) a.sram

shame.NOM.SG (MASC; CLASS I) 'shame' b. slast-jon-a sweet-EVAL-NOM.SG (MASC/FEM; CLASS II) 'person with sweet tooth (affect)'

b. kras-ot-ul-ja

pretty/red-NOM-EVAL-NOM.SG

(MASC/FEM; CLASS II)

'pretty person (affect)' b. styd $-o b-a$ shame-EVAL-NOM.SG (FEM; CLASS II) 'shame (vulg)'

b. sram-ot $-a$

shame-EVAL-NOM.SG (FEM; CLASS II) 'shame (vulg)'

This is summarized in table 2 .

\begin{tabular}{|l|l|}
\hline Affectionate suffixes: Animate & $-a n,-j a s h,-j o n,-u l,-u n,-u r,-u s,-u s h$ \\
\hline Vulgar suffixes: & $-a g,-j a k,-a l,-j a r,-a k h,-i l,-i n,-o k h,-j u g,-u k,-u k h$ \\
i. Animate & $-o b,-o t$ \\
ii. Inanimate &
\end{tabular}

Table 2: Russian evaluative suffixes and animacy

\subsection{Grammatical gender}

In $§ 2.2 .1$, I discuss animate suffixes, and in $§ 2.2 .2$ I deal with inanimate suffixes.

\subsubsection{Animate suffixes}

The same suffix can form nouns of different grammatical genders: masculine, as in (13b); feminine, as in (14b); and common gender (MASC or FEM), as in (15b) and (16b). As noted before, when animate suffixes attach to kinship nouns, the gender of the base is always preserved, as in (13), (14).

(13) MASC $=$ MASC
a. ded
b. ded-ul-ja
grandfather.NOM.SG
grandfather-EVAL-NOM.SG
(MASC; CLASS I)
(MASC; CLASS II)
'grandfather'
'grandfather (affect)' 
(14) $\mathrm{FEM}=\mathrm{FEM}$
a. $b a b-a$
b. $b a b-u l-j a$
grandmother-NOM.SG
grandmother-EVAL-NOM.SG
(FEM; CLASS II)
(FEM; CLASS II)
'grandmother'
'grandmother (affect)'

(15) MASC $\Rightarrow$ COMMON GENDER (MASC OR FEM)
a. chort
b. chert-jak-a
devil.NOM.SG (MASC; CLASS I)
devil-EVAL-NOM.SG (MASC/FEM; CLASS II)
'devil' 'devious person (vulg)'

(16) $\mathrm{FEM} \Rightarrow$ COMMON GENDER (MASC OR FEM)
a. pravd-a
b. pravd-okh-a
truth-NOM.SG (FEM; CLASS II)
truth-EVAL-NOM.SG (MASC/FEM; CLASS II)
'truth'
'truth telling person (vulg)'

Nouns of common gender can trigger either masculine or feminine gender agreement depending on the biological gender of the referent. Such nouns are not uncommon across languages, e.g., Spanish el/la estudiante 'the (masc/fem) student'; Garifuna mútu lé/tó 'this (masc/fem) person' (meaning 'a man' or 'a woman') (Munro 2015: 7); Halkomelem $t^{\theta}$ a/Oə álex 'the (unmarked/fem) sibling' (meaning 'a brother or a sister') (Steriopolo and Wiltschko 2010: 163).

Common gender nouns (MASC or FEM) formed from animate evaluative suffixes can trigger feminine (17a), masculine (17b), or mixed (feminine and masculine; 17c) ${ }^{2}$ gender agreements.
(17) a. Eht-a
grjaz- $n-u l-j a$
vsjo
this-FEM dirty.person-ADJ-EVAL-NOM.SG everything
tut zapachk-al-a.
here make.dirty-PAST-FEM
'This (FEM) dirty person (affect) has made (FEM) everything dirty.'
b. Eht-ot grjaz-n-ul-ja vsjo
this-MASC dirty.person-ADJ-EVAL-NOM.SG everything
tut zapachk-al.
here make.dirty-PAST.MASC
'This (MASC) dirty person (affect) has made (MASC) everything dirty.'
c. ?Eht-a grjaz-n-ul-ja vsjo
this-FEM dirty.person-ADJ-EVAL-NOM.SG everything
tut zapachk-al.
here make.dirty-PAST.MASC
'This (FEM) dirty person (affect) has made (MASC) everything dirty.'

2 Mixed gender agreement is subject to speaker variation and is unaccepted by some native speakers. Examples of mixed gender agreement in Russian can be found in the Russian National Corpus, available at http:// ruscorpora.ru/. 


\subsubsection{Inanimate suffixes}

Inanimate suffixes only form nouns of feminine gender, as in (18). ${ }^{3}$

(18) $\mathrm{FEM}=\mathrm{FEM}$
a. smekh
b. smekh-ot-a

laughter.NOM.SG (MASC; CLASS I) 'laughter' laughter-EVAL-NOM.SG (FEM; CLASS II)
'laughter (vulg)'

\subsection{Summary}

The properties of the nominalizing evaluative suffixes under investigation are summarized in table 3 . They all form nouns of the $-a$-declension. The majority of the suffixes (excluding -ob, $-o t$ ) form animate nouns which belong to different grammatical genders (MASC, FEM, or COMMON). Two vulgar suffixes $(-o b,-o t)$ never change the animacy of the base, as they only attach to inanimate bases and form inanimate nouns; they consistently form feminine nouns.

\begin{tabular}{|l|l|}
\hline $\begin{array}{l}\text { Affectionate suffixes: Animate } \\
\text { (fem/masc/common) }\end{array}$ & $\begin{array}{l}\text {-an, -jash, -jon, }-u l,-u n,-u r,-u s, \\
-u s h\end{array}$ \\
\hline $\begin{array}{l}\text { Vulgar suffixes: } \\
\text { i. Animate (fem/masc/common) } \\
\text { ii. Inanimate (fem) }\end{array}$ & $\begin{array}{l}-a g,-j a k,-a l,-j a r,-a k h,-i l,-i n,- \\
\text { In },-j u g,-u k,-u k h-o b,-o t\end{array}$ \\
\hline
\end{tabular}

Table 3: Russian evaluative suffixes, animacy, and gender

\section{Analysis}

$\S 3.1 .$, I analyze the manner of syntactic attachment of the evaluative suffixes. I cover the question as to whether they attach as syntactic heads or modifiers in the syntactic tree. In §3.2., I analyze their place of syntactic attachment. In §3.3., I discuss morphosyntactic features of the evaluative suffixes. In §3.4., I consider two different syntactic approaches to account for evaluative derivations. Finally, in $\S 3.5$., I argue against the interpretable gender features analysis.

\subsection{Manner of syntactic attachment}

I propose that the evaluative suffixes under investigation are nominalizing heads, as in (19).

(19)

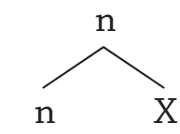

[EVAL]

3 See also examples (11) and (12). 
The evidence comes from the fact that they can attach to various syntactic categories (adjectives, verbs, nouns) and always form nouns, as shown in (20)-(22).

(20) ADJECTIVE $\Rightarrow$ NOUN
a. grjaz $-n-y j$
dirty-ADJ-MASC.NOM.SG
b. grjaz $-n-u l-j a$
dirty-ADJ-EVAL-NOM.SG
(MASC/FEM; CLASS II)
'dirty'
'dirty person (affect)'

(21) VERB $\Rightarrow$ NOUN
a. vypiv $-a-t^{\prime}$
drink-TH-INF
'to drink up'
b. vypiv-okh-a
drink-EVAL-NOM.SG (MASC/FEM; CLASS II) 'boozer (vulg)'

(22) NOUN $=$ NOUN
a. $k o t$
b. kot-jar-a
cat.NOM.SG (MASC; CLASS I)
cat-EVAL-NOM.SG (MASC; CLASS II)
'cat'
'cat (vulg)'

\subsection{Place of syntactic attachment}

The data in (22) above raise the question as to where in the syntactic tree the evaluative suffixes attach. Do they attach to roots, as in (23a), or to syntactic categories, as in (23b)?

(23) a.

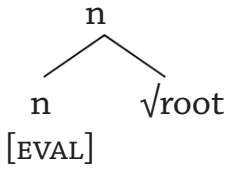

b.

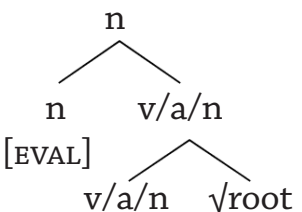

There are strong indications that they attach above syntactic categories, as in the structure (23b) above. One piece of evidence stems from the fact that categoryforming morphology is inside the evaluative suffix, as shown in (24)-(25).

(24) ADJECTIVAL SUFFIX
a. grjaz-n-yj
b. grjaz-n-ul-ja
dirty-ADJ-MASC.NOM.SG
dirty-ADJ-EVAL-NOM.SG (MASC/FEM; CLASS II)
'dirty'
'dirty person (affect)'
C.

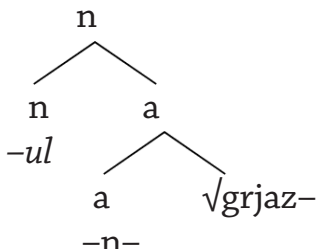


(25) NOMINAL SUFFIX
a. kras-ot-a
b. kras-ot-ul-ja
pretty/red-NOM-NOM.SG
pretty/red-NOM-EVAL-NOM.SG
(FEM; CLASS II)
'beauty'
(MASC/FEM; CLASS II)
'pretty person (affect)'

c.

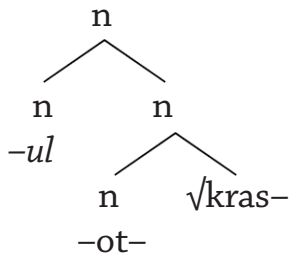

Aside from containing category-forming morphology, evaluative suffixes are also able to attach to compounds, as in (26).
(26) a. kos-o-lap-yj
crook-TH-paw-ADJ.MASC.SG
'awkward'

b. kos-o-lap-in-a crook-TH-paw-EVAL-NOM.SG (MASC/FEM) 'awkward person (vulg)'

\subsection{Morphosyntactic features}

In 3.3 .1$, I discuss the feature [animate]; in 33.3 .2$, I discuss the feature [class].

\subsubsection{The feature [ANIMATE]}

I propose that - with the exception of -ob and -ot, - the evaluative suffixes are specified for the feature [ANIMATE], as in (27).

(27)

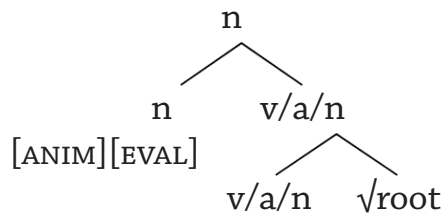

This is evidenced by the fact that they consistently form animate nouns from inanimate bases, as in (28), (29).
(28) a. slast'
b. slast-jon-a
sweet.NOM.SG (FEM; CLASS III)
sweet-EVAL-NOM.SG (MASC/FEM; CLASS II) 'sweet' 'person with sweet tooth (affect)'
(29) a. grjaz-n-yj dirty-ADJ-MASC.NOM.SG 'dirty'
b. grjaz-n-ukh-a dirty-ADJ-EVAL-NOM.SG (MASC/FEM; CLASS II) 'dirty person (vulg)' 
Note in passing that the structure proposed in (27) above is similar to the proposals in Panagiotidis (forthcoming, 9) and Wiltschko (2012), as in (30a) and (30b), respectively, in which animacy is located immediately above $n P$.

(30) a.
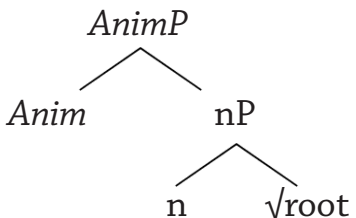

(simplified from Panagiotidis, forthcoming: 9) b. $\quad$ NumP

I-AspP [animate]

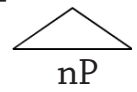

(simplified from Wiltschko 2012)

\subsubsection{The feature [CLASS]}

I propose that the evaluative suffixes are specified for the feature declension [CLASS II], but have no gender feature, ${ }^{4}$ as shown in (31).

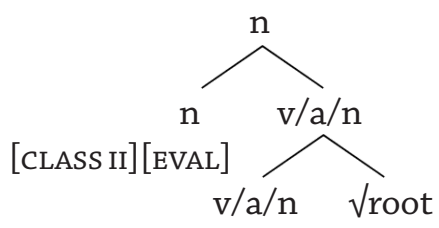

The reason for this proposal is that the evaluative suffixes consistently form nouns of the $-a$-declension (CLASS II), as in (32)-(34).

(32) CLASS I $\Rightarrow$ CLASS II
a. vor
b. vor-jug-a
thief.NOM.SG (MASC; CLASS I)
thief-EVAL-NOM.SG (MASC/FEM; CLASS II)
'thief'
'thief (vulg)'

(33) CLASS II = CLASS II
a. $m a m-a$
b. $m a m-a n-j a$
mother-NOM.SG (FEM; CLASS II)
mother-EVAL-NOM.SG (FEM; CLASS II)
'mother'
'mother (affect)'

(34) CLASS III $\Rightarrow$ CLASS II
a. doch'
b. doch-ur-a
daughter.NOM.SG
daughter-EVAL-NOM.SG
(FEM; CLASS III)
(FEM; CLASS II)
'daughter'
'daughter (affect)'

\footnotetext{
4 This is contrary to Embick (2010), Alexiadou and Müller (2008), and Kramer (2015), among others, who consider [CLASs] a post-syntactic phenomenon (but see Steriopolo 2018 for arguments in favor of [cLAss] being a syntactic feature).
} 
The evaluative suffixes are not specified for the feature [GENDER], because they can form nouns of different genders, as in (35)-(37). Nevertheless, it is important to note that they can change the gender of the base to which they attach. Thus, in (35), a masculine noun becomes a common gender noun when the evaluative suffix -in is attached. In (36), a masculine noun becomes feminine when the evaluative suffix $-o b$ is attached.

(35) MASC $\Rightarrow$ COMMON GENDER (MASC OR FEM)
a. durak
b. durach-in-a
fool.NOM.SG (MASC; CLASS I)
fool-EVAL-NOM.SG (MASC/FEM; CLASS II)
'fool'
'fool (vulg)'

(36) $\mathrm{MASC} \Rightarrow$ FEM
a.styd
b. styd $-o b-a$
shame.NOM.SG (MASC; CLASS I)
shame-EVAL-NOM.SG (FEM; CLASS II)
'shame'
'shame (vulg)'

(37) MASC $=$ MASC
a. brat
b. brat-ukh-a
brother.NOM.SG (MASC; CLASS I)
brather-EVAL-NOM.SG (MASC; CLASS II)
'brother'
'brother (vulg)'

\subsection{Syntactic approaches to account for evaluative derivations}

Here, I discuss which syntactic approach best accounts for evaluative derivations in Russian: a hierarchical structure approach (Chomsky 2000, 2001) or a cyclicity approach (Marantz 2001; Embick 2010; Marvin 2013). To answer this question, I investigate Russian data in which an evaluative suffix attaches to a gendered nominal, as in (38).

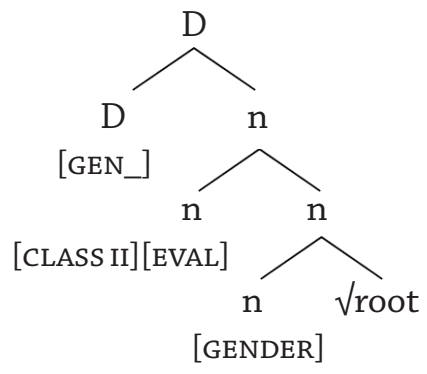

The two approaches make completely different predictions. Consider first the hierarchical structure approach. The probe searches downward into its $c$-command domain for a goal and enters into an Agree relation with the first goal it encounters. In the structure (38), $D$ [GEN_] would agree in gender with the lower $n$ [GENDER] because the higher $n$ [CLASS II] [ EVAL] has no gender feature. Hence it is not a suitable goal. 
Consider now the cyclicity approach. $n$ is a phase head that triggers spell-out of its complement. The spelled-out material is not accessible to later operations (Phase Impenetrability Condition, as in Chomsky 1999, 2000). Thus, in the structure (38), the higher $n$ [EVAL] triggers spell-out of the lower $n$ [GENDER], meaning that $D$ [GEN_] has no access to the lower $n$ [GENDER]. The Russian data in (39) and (40) below show that the cyclicity approach is best suited to account for the data. First, consider the data in (39).

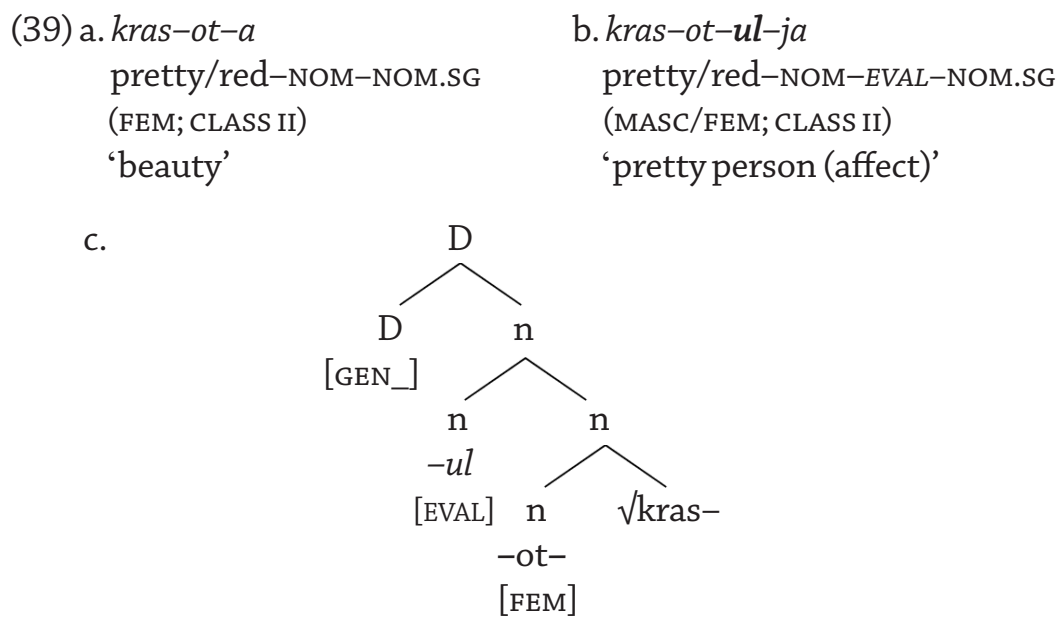

In the structure (39c), the hierarchical structure approach predicts that $D$ [GEN_] would agree with the lower $n$ [FEM], because the higher $n$ [EVAL] is not a suitable goal (it has no gender feature). Thus, the resulting evaluative derivation should be feminine. The cyclicity approach makes a different prediction: gender of $D$ [GEN_] has no access to the lower $n$ [FEM]. Thus, the gender of the resulting evaluative derivation would be unknown (it could be either masculine or feminine, since it denotes a human). The data in (39b) substantiates this assumption. Now consider the data in (40).

(40) a. vor

thief.NOM.SG

(MASC; CLASS I)

'thief' b. vor-jug-a

thief-EVAL-NOM.SG

(MASC/FEM; CLASS II)

'thief (vulg)'

c.

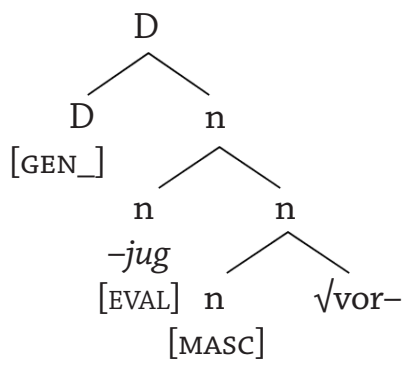


In the structure (40c), the hierarchical structure approach predicts that the evaluative derivation should be masculine, while the cyclicity approach again predicts unknown gender, as in (40b).

Based on this evidence, I conclude that the Russian data support the cyclicity approach (see Kramer 2014: 222-25, who reaches the same conclusions for Amharic and Somali).

It was noted above (\$2.2.1) that kinship nouns behave differently-they do not change the gender of the base when an evaluative suffix attaches to them, as in (41), (42) below. Thus, we must now investigate the essence of the differences between kinship and non-kinship nouns.

(41) MASC $=$ MASC
a.brat
b. brat-ukh-a
brother.NOM.SG (MASC; CLASS I)
brother-EVAL-NOM.SG (MASC; CLASS II)
'brother'
'brother (vulg)'

c.

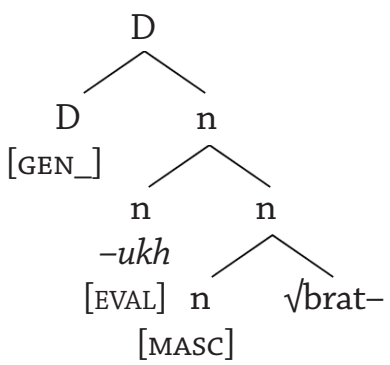

(42) $\mathrm{FEM}=\mathrm{FEM}$
a. sestr-a
b. sestr-ukh-a
sister-NOM.SG (FEM; CLASS II)
'sister'
sister-EVAL-NOM.SG (FEM; CLASS II)
'sister (vulg)'
c.

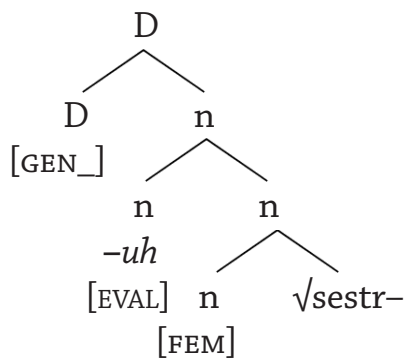

Bobaljik and Zocca (2011) investigate the behavior of nominal predicates under ellipsis and show that there are semantic classes of nominals that differ with respect to whether or not the underived masculine forms carry a presupposition 
of maleness. The data in (43i) show that Russian kinship terms like brat 'brother' carry a presupposition of maleness, while non-kinship terms like vor 'thief' do not. The data in (43ii) show that when an evaluative suffix is attached, it produces no change in the presupposition of maleness. The question arises as to whether kinship nouns may have a special morphosyntactic feature compared to non-kinship nouns. This issue is discussed in the following subsection $\S 3.5$.

(43) APPLYING BOBALJIK AND ZOCCA (2011) TO RUSSIAN KINSHIP NOMINALS

(i) UNDERIVED MASCULINE FORMS

\begin{tabular}{|c|c|c|c|}
\hline $\begin{array}{l}\text { a. }{ }^{*} \text { Petja- } \\
\text { Peter }\end{array}$ & $\begin{array}{l}\text { brat } \\
\text { brother.NOM.SG }\end{array}$ & $\begin{array}{l}i \\
\text { and }\end{array}$ & $\begin{array}{l}\text { Marija } \\
\text { Maria }\end{array}$ \\
\hline
\end{tabular}

\begin{tabular}{|c|c|c|}
\hline $\begin{array}{l}\text { o. Petja- } \\
\text { Peter }\end{array}$ & $\begin{array}{l}\text { vor } \\
\text { thief.NOM.SG }\end{array}$ & $\begin{array}{l}i \\
\text { and }\end{array}$ \\
\hline
\end{tabular}

'Peter is a thief and Maria, too.'

(ii) DERIVED FORMS WITH EVAL SUFFIX
a. ${ }^{*}$ Petja-
brat-ukh-a
i Marija
tozhe.
Peter
brother-EVAL-NOM.SG and
Maria
also
'Peter is a brother (eval) and Maria, too.'
b. Petja-
vor-jug $-a$
i Marija
tozhe.
Peter
thief-EVAL-NOM.SG
and
Maria
too
'Peter is a thief (eval) and Maria, too.'

\subsection{An interpretable gender features approach}

Kramer (2015) proposes that gender features are located on $n$ and come in two different types: interpretable, for natural gender, and uninterpretable, for arbitrary gender, as in (44). The "plain" $n$ has no gender feature and the result is gender by morphological default.

(44) POSSIBLE INVENTORY OF FEATURES
a. $\mathrm{n}$ i[+FEM] Female naturalgender
b. $\mathrm{n}$ i[-FEM] Male naturalgender
c. $\mathrm{n} \quad$ No natural gender (or it is irrelevant/unknown)
d. $\mathrm{n}$ u [-FEM] Male arbitrary gender
e. $\mathrm{n} \quad \mathrm{u}[+\mathrm{FEM}]$ Female arbitrary gender
(Kramer 2015: 50, 170)

According to Kramer (2015), interpretable features are legible at LF and can change the interpretation of a linguistic structure (e.g., they can insert a denotation, see Zamparelli 2008: 170). Uninterpretable features are illegible at LF; they do not affect interpretation. Thus, there are no inherent male/female meanings on roots like $\sqrt{ }$ mother, $\sqrt{ }$ father. As Kramer (2015: 52) states, "Licensing a root in a particular nominal context is what makes it interpreted as male or female". 
(45) SEMANTIC LICENSING CONDITIONS: 'mother' (modified from Kramer 2015: 51) [n $i[+\mathrm{FEM}][$ mother $]]=$ 'female parent'

This approach becomes potentially problematic when it comes to non-nominal derivations with a kinship meaning. The analysis in (45) predicts that such derivations (i) either cannot have a male/female interpretation at all (the Russian data in (46) contradict this), or (ii) they must be universally derived from a nominal that always has an interpretable gender feature, as structured in (46d). Further research will be able to show whether (46d) is a correct structure.

(46) a. RUSSIAN VERBS:

$$
\begin{aligned}
& u-s y n-o v-i t \text { ' to adopt a son' } \\
& u \text {-doch-er-it' 'to adopt a daughter' } \\
& \text { zhen-it'-sja 'to get married to a woman' } \\
& \text { vyjti za-muzh 'to get married to a man' }
\end{aligned}
$$

b. RUSSIAN ADJECTIVES: mat-erinskaja ljubov' 'mother's love'

c. RUSSIAN ADVERBS: razdelit'po-brat-ski 'to divide equally

(lt.: like among brothers)'

d.

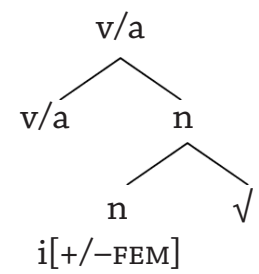

Furthermore, if Kramer's (2015) approach is correct, we expect that in languages with no grammatical gender, there is either (i) no male/female interpretation at all, or (ii) if there is such an interpretation, the interpretable gender features must be present in the syntax. This leads to the question if there is any need to assume syntactic gender features in languages with no syntactic gender agreement.

If we apply Kramer's (2015) analysis to the Russian data in question, the kinship noun brat 'brother' would have the interpretable gender feature i[-FEM] (47a), while vor 'thief' would not have this feature (47b); these nouns would differ in presence or absence of the syntactic feature [GENDER].

(47) a.

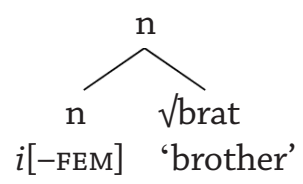

b.

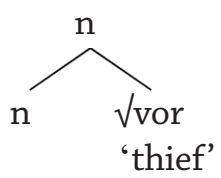

In this case, EVAL suffixes would be realizations of different syntactic feature bundles, as in (48). 
(48) a. n, [EVAL], i[+FEM] Female natural gender

b. $\mathrm{n},[\mathrm{EVAL}], \mathrm{i}[-\mathrm{FEM}] \quad$ Male natural gender

c. n, [EVAL] No natural gender (or it is irrelevant/unknown)

All feature bundles in (48) contain the category feature $n$ and the semantic feature [EVAL]. However, they differ in terms of their gender features: (48a) hasi [+FEM]; (48b) has i[-FEM], and (48c) has no gender feature (morphological default). ${ }^{5}$ However, there are three problems which might arise with the approach taken in (48).

First, there is the problem of potential over-generation. Every EVAL suffix, as in (49b), would have three homophonous counterparts ( $n \mathrm{i}[+\mathrm{FEM}], n \mathrm{i}[-\mathrm{FEM}]$, and "plain" $n)$, as in (50a, b, c).
(49) a.grjaz $-n-y j$
dirty-ADJ-MASC.NOM.SG
'dirty'

$$
\begin{aligned}
& \text { b. } \text { grjaz-n-ul-ja } \\
& \text { dirty-ADJ-EVAL-NOM.SG } \\
& \text { (MASC/FEM; CLASS II) } \\
& \text { 'dirty person (affect)' }
\end{aligned}
$$

(50) a.

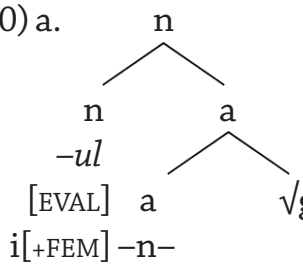

b.

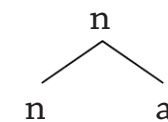

Vgrjaz- [EVAL] a

$\mathrm{i}[-\mathrm{FEM}]-\mathrm{n}-$ c.

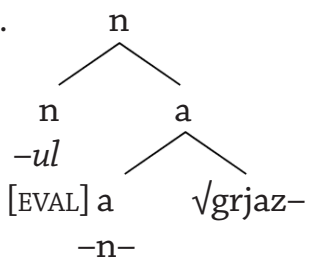

Second, the feature [CLASs] is not in Kramer's system. Thus, gender as a default, as in (50c), would be unclear in Russian, as default gender can be feminine (for cLASs II nouns) or masculine (for cLAss I nouns) in Russian. For example, in Russian cLAss

\begin{tabular}{|c|c|c|}
\hline $\begin{array}{l}\text { - Tam } \\
\text { there }\end{array}$ & $\begin{array}{l}\text { grjaz-n-ul-ja } \\
\text { dirty-ADJ-EVAL-NOM.SG (CLASS II) }\end{array}$ & $\begin{array}{l}\text { sid-it. } \\
\text { sit-PRES }\end{array}$ \\
\hline \multicolumn{3}{|c|}{ 'A dirty person (affect) is sitting there.' } \\
\hline$-K a k-a j a$ & grjaz-n-ul-ja? & \\
\hline what-FEM & dirty-ADJ-EVAL-NOM.SG (CLASS II) & \\
\hline hat (FEN & dirty person (affect)?' & \\
\hline
\end{tabular}
II nouns, when the gender of the referent is unknown or unimportant, feminine gender agreement is most likely to be used, (51).

(51) $\mathrm{n}$, [CLASS II] $\Rightarrow$ [FEM]

In Russian CLASS I nouns, however, when the gender of the referent is unknown (or unimportant), masculine gender agreement is most likely to be used, as in (52). 
(52) $\mathrm{n},[\mathrm{CLASS} \mathrm{I}] \Rightarrow[\mathrm{MASC}]$

$\begin{array}{ll}\text { - Tam vrach } & \text { sid-it. } \\ \text { there doctor.NOM.SG (CLASS I) } & \text { sit-PRES } \\ \text { 'A doctor is sitting there.' } & \\ \text { - Kak-oj vrach? } & \\ \text { what-MASC doctor.NOM.SG (CLASS I) } & \\ \text { 'What (MASC) doctor?' }\end{array}$

The third potential problem with this approach is under-generation. Although Kramer's (2015) system fully accounts for feminine and masculine gender agreements, it cannot account for mixed gender agreement, as the author herself states, see (53), repeated from (17c) above.

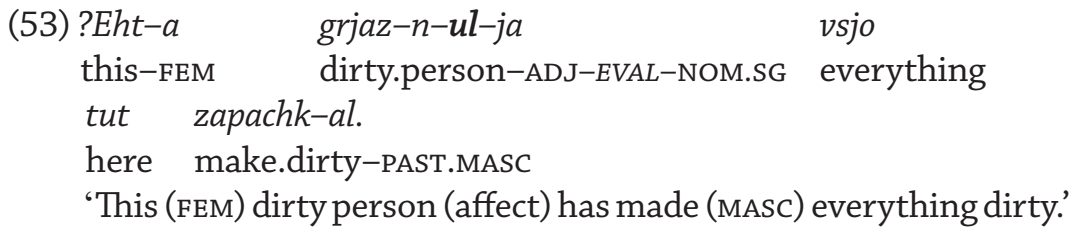

To summarize, if we apply Kramer's (2015) system to Russian evaluative derivations, the system seems to either over-generate, as in (50), with three homophonous suffixes, or under-generate, as in (53), with mixed gender agreement. Therefore, I assume instead that natural gender 'male'/'female' is not a morhosyntactic feature, but rather a part of the root meaning (Steriopolo and Wiltschko 2010; Kučerová 2018). In other words, I assume no syntactic differences between the nouns 'brother' and 'thief,' as diagramed in (54) below. The difference between them is of semantic nature: the root $\sqrt{b r a t}$ 'brother' has a presupposition of maleness as part of its root meaning (see Bobaljik and Zocca 2011, discussed above), while the root $\sqrt{ }$ vor ' thief' does not.

$(54)$

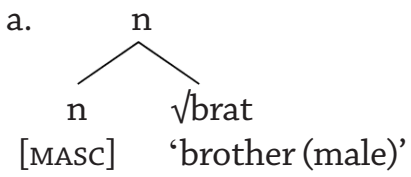

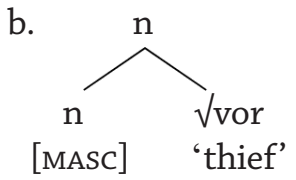

\section{Conclusions}

I have presented a morphosyntactic analysis of evaluative nominalizing suffixes in Russian within the framework of Distributed Morphology.

I have argued that the evaluative suffixes under investigation are nominal heads which are specified for the morphosyntactic features [ANIMATE] and [CLASS II], but they have no grammatical gender features, as diagrammed in (55). 
(55)

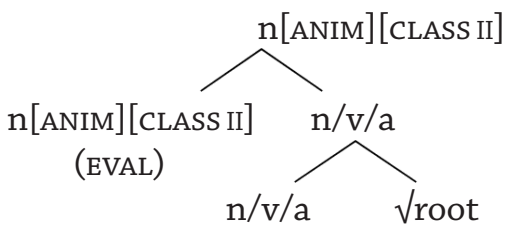

I have proposed that kinship nouns, such as syn 'son'/brat 'brother', retain the gender of the base not because the morphosyntactic feature [GENDER] is present in the derivation (I have argued that it is not), but rather because a presupposition of maleness is an inherent part of the root meaning.

\section{References}

Alexiadou, Artemis, and Gereon Müller (2008). Class Features as Probes. Bachrach, Asaf, and Andrew Nevins, eds. Inflectional Identity. Oxford: Oxford University Press, 101-155

Bobaljik, Jonathan D., and Cynthia Levart Zocca (2011). Gender Markedness: The Anatomy of a Counter-Example. Morphology 21(2): 141-166

Brown, Dunstan, and Andrew Hippisley (2012). Network Morphology: A Defaults-Based Theory of Word Structure. Cambridge: Cambridge University Press

Chomsky, Noam (1999). Derivation by Phase. Cambridge, MA: MIT Press

Chomsky, Noam (2000). Minimalist Inquiries: The Framework. Martin, Roger, David Michaels, Juan Uriagereka, and Samuel J. Keyser, eds. Step by Step: Essays on Minimalist Syntax in Honor of Howard Lasnik. Cambridge, MA: MIT Press, 89-155

Chomsky, Noam (2001). Derivation by Phase. Kenstowicz, Michael, ed. Ken Hale: A Life in Language. Cambridge, MA: MIT Press, 1-52

Dressler, Wolfgang, and L. Merlini Barbaresi (1994). Morphopragmatics: Diminutives and Intensifiers in Italian, German, and Other Languages. Berlin: Mouton de Gruyter

Embick, David (2010). Localism versus Globalism in Morphology and Phonology. Cambridge, MA: MIT Press

Halle, Morris, and Alec Marantz (1993). Distributed Morphology and the Pieces of Inflection. Hale, Ken, and Samuel J. Keyser, eds. The View from Building 20: Essays in Linguistics in Honor of Sylvain Bromberger. Cambridge, MA: MIT Press, 111-176

Kramer, Ruth (2014). Gender in Amharic: A Morphosyntactic Approach to Natural and Grammatical Gender. Language Sciences 43: 102-115.

https://doi.org/10.1016/j.langsci.2013.10.004

Kramer, Ruth (2015). The Morphosyntax of Gender. Oxford Studies in Theoretical Linguistics 58. Oxford: Oxford University Press

Kučerová, Ivona (2018). $\varphi$-features at the Syntax-Semantics Interface: Evidence from Nominal Inflection. Linguistic Inquiry 49(4): 813-845.

https://doi.org/10.1162/ling_a_00290

Manova, Stela (2004). Derivation versus Inflection in Three Inflecting Languages. Dressler, Wolfgang U., Dieter Kastovsky, Oskar E. Pfeiffer, Franz Rainer, Francesco Gardani, and Markus A. Pöchtrager, eds. Morphology and Its Demarcations. Amsterdam: Benjamins, 233-252. https://doi.org/10.1075/cilt.264.15man 
Marantz, Alec (1997). No Escape from Syntax: Don't Try Morphological Analysis in the Privacy of Your Own Lexicon. University of Pennsylvania Working Papers in Linguistics 4(2), Article 14. https://repository.upenn.edu/pwpl/vol4/iss2/14

Marantz, Alec (2001). Words. Paper presented at WCCFL 20, University of Southern California, Los Angeles.

Marvin, Tatjana (2013). Is Word Structure Relevant for Stress Assignment? Marantz, Alec, and Ora Matushansky, eds. Distributed Morphology Today: Morphemes for Morris Halle. Cambridge, MA: MIT Press.

https://doi.org/10.7551/mitpress/9780262019675.003.0005

Munro, Pamela (2015). Garifuna Gender. Handout from the 2nd Linguistics Symposium, Department of Modern Languages, California State University Dominguez Hills, March 12.

Panagiotidis, Phoevos. Forthcoming. (Grammatical) Gender Troubles and the Gender of Pronouns. Mathieu, Eric, and Gita Zareikar, eds. Gender, Noun Classification, and Determination. Oxford and New York: Oxford University Press

Scalise, Sergio (1984). Generative Morphology. Dordrecht: Foris

Scalise, Sergio (1988). The Notion of 'Head' in Morphology. Yearbook of Morphology 1: 229-45

Stankiewicz, Edward (1968). Declension and Gradation of Russian Substantives. The Hague: Mouton

Steriopolo, Olga (2008). Form and Function of Expressive Morphology: A Case Study of Russian. $\mathrm{PhD}$ dissertation. University of British Columbia. http://hdl.handle.net/2429/424

Steriopolo, Olga (2017). Nominalizing evaluative suffixes in Russian: The interaction of declension class, gender, and animacy. Poljarnyj vestnik: Norwegian Journal of Slavic Studies 20: 18-44

Steriopolo, Olga (2018). Morphosyntax of gender in Russian sex-differentiable nouns. Journal of Slavic Linguistics 26(2): 1-29

Steriopolo, Olga, and Martina Wiltschko (2010). Distributed gender Hypothesis. Zybatow, Gerhild, Philip Dudchuk, Serge Minor, and Ekaterina Pshehotskaya, eds. Formal Studies in Slavic Linguistics. New York: Peter Lang, 155-172

Stump, Gregory (1991). A Paradigm-Based Theory of Morphosemantic Mismatches. Language 67(4): 675-725. https://doi.org/10.2307/415074

Stump, Gregory (2001). Inflectional Morphology: A Theory of Paradigm Structure. Cambridge: Cambridge University Press

Vinogradov, Victor V. (1972). Russkijjazyk. 2nd ed. Moscow: Uchpedgiz

Wiltschko, Martina (2012). Decomposing the Count-Mass Distinction: Evidence from Languages that Lack It. Massam, Diane, ed. Count and Mass across Languages. Oxford: Oxford University Press, 146-171

Zamparelli, Roberto (2008). On the Interpretability of $\varphi$-Features. De Cat, Cécile, and Katherine Demuth, eds. The Bantu-Romance Connection. A comparative investigation of verbal agreement, DPs, and information structure. Amsterdam: John Benjamins, 167199. https://doi.org/10.1075/la.131.11zam 


\section{Ruski evaluacijski nominalizirajući sufiksi i promjene u rodu}

Ovaj rad donosi istraživanje ruskih evaluacijskih nominalizirajućih sufikasa koji dovode do promjene sintaktičke kategorije i kategorijskih obilježja osnove poput živosti, sklonidbene vrste i roda. Većina tih sufikasa sustavno tvori evaluacijske izvedenice druge sklonidbene vrste ( $a$-sklonidba) s obilježjem živosti. No kada se radi o gramatičkome rodu, čini se da nema dosljednosti u rodu evaluacijskih izvedenica pa kod osnova imenica koje označavaju rodbinske odnose dolazi do promjene u rodu te sustavno nastaju evaluacijske izvedenice zajedničkoga roda (muškoga ili ženskoga). Kod osnova koje označavaju rodbinski odnos pak ne dolazi do promjene roda.

U radu se analizira ta pojava unutar teorijskoga okvira distribuirane morfologije pa će rad biti zanimljiv teorijskim lingvistima, jezičnim tipolozima, ruskim lingvistima i edukatorima te svakomu koga zanima gramatički rod.

Keywords: evaluative suffixes, nominalizer, grammatical gender, declension class, kinship nouns, Russian

Ključne riječi: evaluacijski sufiksi, nominalizator, gramatički rod, sklonidbena vrsta, rodbinski nazivi, ruski jezik

Acknowledgments: Grateful thanks go to the anonymous reviewers for useful comments and suggestions. This work is an elaboration of my 2017 study "Nominalizing evaluative suffixes in Russian: The interaction of declension class, gender, and animacy". This research was supported by a DFG (German Research Foundation) research grant to Olga Steriopolo (4/2016 - 3/2019). 